\title{
ATP-Sensitive Potassium Channels in Neonatal and Adult Rabbit Ventricular Myocytes
}

\author{
FUHUA CHEN, GLENN T. WETZEL, WILLIAM F. FRIEDMAN, AND THOMAS S. KLITZNER \\ Department of Pediatrics, Division of Cardiology, University of California at Los Angeles, School of Medicine, \\ Los Angeles, California 90024
}

\begin{abstract}
The properties of the ATP-sensitive potassium $\left(K_{\mathrm{ATP}}\right)$ current were studied in freshly isolated rabbit ventricular myocytes using the patch clamp technique. Removing ATP from the bath (intracellular) solution activated a large $\mathrm{K}^{+}$conductance in patches from neonatal cells with properties similar to those of $\mathbf{K}_{\mathrm{ATP}}$ channels in other preparations. In membrane patches from neonatal ventricular myocytes, the density of $\mathbf{K}_{\mathrm{ATP}}$ channels was higher than the density of inwardly rectifying $\mathrm{K}^{+}$channels and the mean patch $K_{\text {ATP }}$ current was approximately 10 times that of the inwardly rectifying $\mathrm{K}^{+}$current, at a patch membrane potential of $-60 \mathrm{mV}$. Glibenclamide $(10 \mu \mathrm{M})$ in the bath solution decreased the number of functional $K_{\text {ATP }}$ channels, the open-state probability, and the mean patch membrane current. The single-channel conductance of the $\mathbf{K}_{\mathrm{ATP}}$ channel was dependent on the external $\mathrm{K}^{+}$ concentration, and the relationship between channel conductance and external $\mathrm{K}^{+}$concentration was fit by an exponential equation. In addition, the voltage dependence, channel density, and open-state probability of this channel were compared between neonatal and adult isolated ventricular myocytes. The single-channel conductance and channel density of the $K_{\mathrm{ATP}}$ channel in neonatal myocytes were significantly smaller than in adult cells. These results suggest that age-related changes occur in the properties of $\mathrm{K}_{\mathrm{ATP}}$ channels. (Pediatr Res 32: 230-235, 1992)
\end{abstract}

\section{Abbreviations}

$\mathrm{I}_{\mathrm{K} 1}$, inwardly rectifying $\mathrm{K}^{+}$current

$K_{\text {ATP }}$ channel, ATP-sensitive $\mathrm{K}^{+}$channel

HEPES, $N$-2-hydroxyethylpiperazine- $N^{\prime}$-2-ethanesulfonic acid

$\mathbf{P}_{\text {open, }}$ open-state probability

$I_{\text {mean, }}$ mean patch current

$\mathrm{pS}$, picosiemens

$\left[\mathrm{K}^{+}\right], \mathrm{K}^{+}$concentration

$\left[\mathrm{K}^{+}\right]_{0}$, external $\mathrm{K}^{+}$concentration

$\left[\mathrm{K}^{+}\right]_{\text {i, }}$, internal $\mathbf{K}^{+}$concentration

Near the resting membrane potential $(\sim-80 \mathrm{mV})$, potassium is the dominant permeant cation in ventricular myocardium (1). However, outward $\mathrm{K}^{+}$currents become quite small in the membrane potential range near the action potential plateau, due to inward rectification of the $\mathrm{K}^{+}$current-voltage relation (2). During

Received September 23, 1991; accepted March 6, 1992.

Correspondence and reprint requests: Thomas S. Klitzner, M.D., Ph.D., Department of Pediatrics, UCLA School of Medicine, Los Angeles, CA 90024.

Supported in part by funding from the NIH (HL-01347), the American Heart Association, Greater Los Angeles Affiliate (788 IG), and the Variety Club, J.H. Nicholson Endowment. Dr. Chen is supported by a Young Investigator Award from the American Academy of Pediatrics, Section on Cardiology. metabolic inhibition, large $\mathrm{K}^{+}$currents develop and the $\mathrm{K}^{+}$ current-voltage relation may become almost linear $(3,4)$. Under these conditions, increased outward current results in action potential shortening, thereby decreasing $\mathrm{Ca}^{2+}$ influx and developed tension. In addition, the increase in extracellular $\mathrm{K}^{+}$may result in a dispersion of refractoriness, precipitating arrhythmias and abnormal contractions during hypoxia or ischemia (5).

Recent studies suggest that increased $\mathrm{K}^{+}$current in hypoxic and ischemic myocardium is related to the presence of $\mathrm{K}_{\mathrm{ATP}}$ channels that are activated when internal ATP levels fall $(4,6$, 7). $\mathrm{K}_{\mathrm{ATP}}$ channels have also been identified by single-channel recording techniques in cells from other tissues (8).

Although the $\mathrm{K}_{\text {ATP }}$ channel has been extensively investigated in a variety of adult cardiac myocytes, information regarding the characteristics of the channel in immature mammalian heart is limited to cultured rat ventricular cells (9). Further, the properties of the channel have not been compared between neonatal and adult myocytes. Using the patch clamp technique for singlechannel recording, we have characterized the single-channel conductance properties, channel density, and open-state probability of this channel in the freshly isolated neonatal rabbit ventricular myocytes. In addition, the effects of reduction in cytoplasmic ATP concentration on the outward $\mathrm{K}^{+}$current and action potential duration have been investigated. Comparison of results obtained from neonatal and mature myocytes suggests significant differences in $\mathrm{K}_{\mathrm{ATP}}$ channel properties between the two age groups.

\section{MATERIALS AND METHODS}

Preparation. Isolated ventricular myocytes were obtained from neonatal $(2-5 \mathrm{~d}$ old, mean \pm SEM $3.4 \pm 0.3 \mathrm{~d}, n=16)$ New Zealand White rabbits $(50-125 \mathrm{~g}, 108 \pm 6.8 \mathrm{~g}, n=14)$ by enzymatic dissociation as described previously $(10,11)$. In brief, neonatal rabbits were anticoagulated with 1000 units of heparin and anesthetized with pentobarbital $(50 \mathrm{mg})$ by intraperitoneal injection. The heart was rapidly excised. The aorta was cannulated and perfused for $3 \mathrm{~min}$ at a rate of $2.5 \mathrm{~mL} / \mathrm{min}$ with $\mathrm{Ca}^{2+}$ free Tyrode's solution containing (in $\mathrm{mM}$ ) NaCl, 136; $\mathrm{KCl}, 5.4$; $\mathrm{NaH}_{2} \mathrm{PO}_{4}, 0.33 ; \mathrm{MgCl}_{2}, 1$; HEPES, 10 ; mannitol, 4; thiamine $\mathrm{HCl}, 0.6$; glucose, 10; and pyruvic acid, 2 . The perfusate was switched to $\mathrm{Ca}^{2+}$-free Tyrode's solution containing collagenase (300 U/mL, Type 1; Sigma Chemical Co., St. Louis, MO) and protease $(0.35 \mathrm{U} / \mathrm{mL}$, Type XIV; Sigma Chemical Co.), which was recirculated with a peristaltic pump (Minipulse 2; Gilson, Middleton, WI) for 7 to $9 \mathrm{~min}$. Thereafter, enzymes were washed out for 3 min with $0.1 \mathrm{mM} \mathrm{Ca}{ }^{2+}$ Tyrode's solution containing (in $\mathrm{mM}$ ) NaCl, $136 ; \mathrm{KCl}, 5.4 ; \mathrm{CaCl}_{2}, 0.1 ; \mathrm{NaH}_{2} \mathrm{PO}_{4}, 0.33 ; \mathrm{MgCl}_{2}$, 1; HEPES, 10; mannitol, 4; thiamine $\mathrm{HCl}, 0.6$; glucose, 10; and pyruvic acid, 2 . The ventricle was opened and gently shaken in $0.1 \mathrm{mM} \mathrm{Ca}^{2+}$ Tyrode's solution to disperse individual, relaxed myocytes.

Myocytes from adult rabbits ( 3 to $3.5 \mathrm{~kg}$ ) were isolated in a similar fashion. After i.v. anticoagulation (heparin, $1500 \mathrm{U}$ ) and 
sedation (pentobarbital, $150 \mathrm{mg}$ ), hearts were excised and perfused at a rate of $45 \mathrm{~mL} / \mathrm{min}$. Solution composition was identical to that used for neonatal rabbits, but enzyme perfusion time was increased to 40 to $45 \mathrm{~min}$. The viability of myocytes prepared in this fashion and the suitability for physiologic studies has been discussed previously (10-12).

Patch clamp technique. Ventricular cells were placed in a small volume recording chamber $(1 \mathrm{~mL})$ on the stage of an inverted microscope (Diaphot, Nikon Inc., Garden City, NY). A standard patch clamp technique, similar to that of Hamill et al. (13), was used and has been described previously (11). After formation of a gigaseal between the pipette tip and the surface membrane of a myocyte, a membrane patch was pulled from the cell and currents recorded in the inside-out patch configuration. A List EPC-7 patch clamp amplifier (List-Electronic, Darmstadt-Eberstadt, Germany) was used to measure single channel currents using Corning soft, thin-walled 8161 glass capillaries (Corning Glass Co., Horsehead, NY) with a tip resistance of 2-6 M $\Omega$ (typically $4 \mathrm{M} \Omega$ ) when filled with internal solution. Sealing resistance varied from 10 to $25 \mathrm{G} \Omega$. Single-channel currents and membrane potential were displayed on a storage oscilloscope (5113; Tektronix, Beaverton, OR) and recorded on a Gould chart recorder (Brush 440; Gould Inc., Cleveland, $\mathrm{OH}$ ) or digitized $(1 \mathrm{kHz})$ and stored on the hard disk of a microcomputer (IBM AT, IBM Co., White Plains, NY), using Axolab 1100 acquisition hardware and pCLAMP software (Axon Instruments, Burlingame, CA). Currents were low-pass filtered at $100-200 \mathrm{~Hz}$ with an eight-pole bessel filter (902LPF; Frequency Devices Inc., Haverhill, MA).

$\mathrm{P}_{\text {open }}$ was calculated as the mean $\mathrm{K}^{+}$channel current for a given patch $\left(\mathrm{I}_{\text {mean }}\right)$ divided by the maximum superposition number ( $N$, the estimated number of active channels observed in the patch) multiplied by the unitary current $(i)$ :

$$
\mathrm{P}_{\text {open }}=\mathrm{I}_{\text {mean }} /(\mathrm{Ni})
$$

$\mathrm{I}_{\text {mean }}$ was determined by subtracting the baseline current from the measured current averaged over at least $10 \mathrm{~s}$.

For single-channel recording, the standard bath (intracellular) solution contained (in $\mathrm{mM}$ ) $\mathrm{KCl}, 140$; HEPES, 5; EGTA, 2; $\mathrm{CaCl}_{2}, 0.5 ; \mathrm{MgCl}_{2}, 2 ; \mathrm{ATP}, 2$; and $\mathrm{KOH}$ to bring the $\mathrm{pH}$ to 7.1 (total $\left[\mathrm{K}^{+}\right]=150 \mathrm{mM}$ ) (14). To activate the $\mathrm{K}_{\mathrm{ATP}}$ channel, ATP was removed from the bath solution. In some experiments, glibenclamide $\left(10 \mu \mathrm{M}\right.$, Sigma Chemical Co.), a specific $\mathrm{K}_{\mathrm{ATP}}$ channel blocker (15), was added to the bath solution to determine its effects on the $\mathrm{K}_{\mathrm{ATP}}$ channel in neonatal cells. In most experiments, the pipette (extracellular) solution contained (in $\mathrm{mM}$ ) $\mathrm{KCl}, 150$; HEPES, 5; and $\mathrm{KOH}$ to bring the $\mathrm{pH}$ to 7.3 . When lower $\left[\mathrm{K}^{+}\right]$solutions were used, $\mathrm{NaCl}$ was substituted isosmotically for $\mathrm{KCl}$. All experiments were carried out at $23^{\circ} \mathrm{C}$, and each experiment was completed within $30 \mathrm{~min}$ of patch formation.

Whole cell voltage clamp recording. The effect of removing intracellular ATP on whole cell $\mathrm{K}^{+}$currents was evaluated using the whole cell voltage clamp configuration. Whole cell $\mathrm{K}^{+}$currents were measured upon puncture of the cell membrane (control) and after $20 \mathrm{~min}$ of cell dialysis with ATP-free internal solution. In these experiments, the bath solution contained (in $\mathrm{mM}) \mathrm{NaCl}, 136 ; \mathrm{KCl}, 5.4 ; \mathrm{CaCl}_{2}, 1.8 ; \mathrm{MgCl}_{2}, 1 ; \mathrm{NaH}_{2} \mathrm{PO}_{4}, 0.3$; HEPES, 10; mannitol, 4; glucose, 10; pyruvic acid, 4; and $\mathrm{NaOH}$ to bring the $\mathrm{pH}$ to 7.3 ; the internal pipette solution contained (in mM) KCl, 120; EGTA, 14; HEPES, 20; $\mathrm{NaH}_{2} \mathrm{PO}_{4}, 10 ; \mathrm{MgCl}_{2}$ 2; $\mathrm{CaCl}_{2}, 1$; and $\mathrm{KOH}$ to adjust $\mathrm{pH}$ to 7.1 . The cell membrane was held at $-80 \mathrm{mV}$ and clamped for $800 \mathrm{~ms}$ to potentials of -100 to $+80 \mathrm{mV}$ in $20-\mathrm{mV}$ increments. To ensure adequate voltage clamp control, the series resistance $\left(R_{s}\right)$ between the current-to-voltage converter and cell membrane was measured using the $\mathrm{G}$-series $\left(\mathrm{G}_{\mathrm{s}}\right)$ compensation circuitry of the patch clamp amplifier. In neonatal cells, $G_{s}$ averaged $0.17 \pm 0.03$ microsiemens, or $R_{s}=5-7 \mathrm{M} \Omega\left(R_{s}=1 / G_{s}\right)$. Thus, in whole cell voltage clamp experiments, the voltage drop across the series resistance was $\leq 3 \mathrm{mV}$ for the maximum measured current (400 pA). This is well within the tolerance established for whole cell recording (16).

Action potential recording. Action potentials were measured in isolated myocytes using the patch clamp amplifier in the current clamp mode. After establishing electrical continuity between the microelectrode and the cell interior, cells were stimulated at 12/ min by passing $10-\mathrm{ms}$ current pulses at $1.5 \times$ threshold. As for whole cell $\mathrm{K}^{+}$current recording, action potential duration was measured both upon the puncture of the cell membrane and after $20 \mathrm{~min}$ of dialysis of the cell interior with ATP-free pipette solution. Action potentials were recorded, digitized, and stored on a computer (IBM AT) for later analysis. The bath and pipette solution were the same as for whole cell voltage clamp experiments.

Statistical methods. Data are presented as mean \pm SEM. Groups were compared using a two-tailed $t$ test. A $p$ value of $<$ 0.05 was used to indicate significance. Slopes of lines were calculated by linear regression. Statistical analysis was performed using BMDP software (Los Angeles, CA).

\section{RESULTS}

Identification of the $K_{\mathrm{ATP}}$ channel in neonatal excised membrane patches. Figure 1 shows single-channel currents recorded from a typical neonatal membrane patch with $[\mathrm{K}]_{\mathrm{i}}=[\mathrm{K}]_{\mathrm{o}}=150$ $\mathrm{mM}$ and the membrane potential held at $-60 \mathrm{mV}$. With $2 \mathrm{mM}$ ATP present in the bath (intracellular) solution, no channel openings were observed (beginning of the upper trace). Removing ATP from the bath solution activated a large conductance channel (Fig. 1, upper trace), which failed to open when ATP was restored to the bathing solution. The emergence of this channel upon removal of ATP was reversible and reproducible (Fig. 1, lower trace). Equivalent results were recorded from a total of 14 inside-out membrane patches. These currents are similar to those recorded from the ATP-sensitive $\mathrm{K}^{+}$channel previously characterized in adult ventricular myocytes (6) and in other preparations (8).

Voltage-dependence of the $K_{\mathrm{ATP}}$ channel in neonatal cells When excised membrane patches from neonatal rabbit ventricular myocytes were exposed to symmetrical $\mathrm{K}^{+}$solution $\left(\left[\mathrm{K}^{+}\right]_{\mathrm{o}}\right.$ $\left.=\left[\mathrm{K}^{+}\right]_{\mathrm{i}}=150 \mathrm{mM}\right)$, the current flowing through open $\mathrm{K}_{\mathrm{ATP}}$ channels had a reversal potential of approximately $0 \mathrm{mV}$, and the current amplitude was dependent on the membrane potential. Figure $2 A$ shows single-channel current records at various potentials in a typical membrane patch from a neonatal myocyte. The current-voltage relation for this patch (Fig. $2 B$ ) was nearly

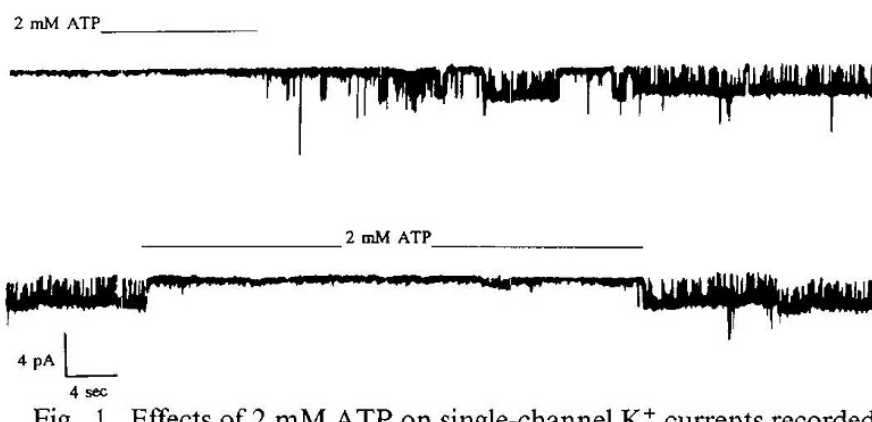

Fig. 1. Effects of $2 \mathrm{mM}$ ATP on single-channel $\mathrm{K}^{+}$currents recorded from an inside-out membrane patch excised from a typical neonatal ventricular myocyte. Downward deflections correspond to current flowing through the membrane from outside to inside. With ATP (2 mM) present in the bath (intracellular) solution, there were no channel openings. Removing ATP from the bath solution caused the channels to open with a unitary current of $3.4 \mathrm{pA}$ (channel conductance $=56.6 \mathrm{pS}$ ). Addition of $2 \mathrm{mM}$ ATP rapidly inactivated the channels. The results were reproducible, suggesting that the channel opening is regulated by the intracellular ATP concentration. (The membrane potential was held at $-60 \mathrm{mV},\left[\mathrm{K}^{+}\right]_{\mathrm{o}}=\left[\mathrm{K}^{+}\right]_{\mathrm{i}}=150 \mathrm{mM}$.) 


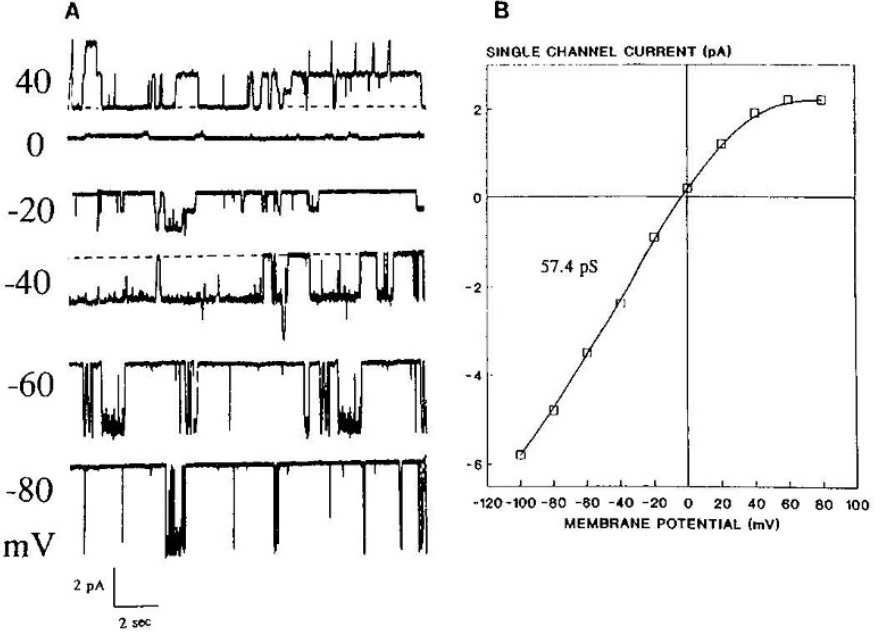

Fig. 2. Voltage dependence of a typical single $\mathrm{K}_{\mathrm{ATP}}$ channel recorded from a neonatal myocyte. $A$, Current traces recorded from a typical membrane patch. The membrane was held at the potentials indicated at the left of each trace. External and internal $\left[\mathrm{K}^{+}\right]$were equal to $150 \mathrm{mM}$, and the zero current potential was approximately $0 \mathrm{mV}$. When the patch was held at potentials positive to the $\mathrm{K}^{+}$equilibrium potential, a significant outward current was seen. The magnitude of the outward current at $+40 \mathrm{mV}$ is almost equal to the magnitude of the inward current at $-40 \mathrm{mV}$, indicating a fairly linear current-voltage relation in this membrane potential range. $B$, The magnitude of the single-channel current ( $y$ axis) plotted $v s$ membrane potential ( $x$ axis) for the experiment shown in $A$. The single-channel current-voltage relation for membrane potentials negative to $+20 \mathrm{mV}$ can be approximated by a straight line yielding a single-channel conductance of $57.4 \mathrm{pS}$.

linear over the voltage range from -100 to $+20 \mathrm{mV}$ with a slope conductance of $57.4 \mathrm{pS}$. However, at membrane potentials positive to $+20 \mathrm{mV}$, some inward rectification of the current through the $\mathrm{K}_{\mathrm{ATP}}$ channel was seen.

Properties of the $K_{\mathrm{ATP}}$ channel. To determine the $\mathrm{K}^{+}$dependence of the $\mathrm{K}_{\mathrm{ATP}}$ single-channel conductance $(\gamma)$ in neonatal ventricular myocytes, single-channel currents were measured with $5.4,11,40,70$, and $150 \mathrm{mM} \mathrm{K}^{+}$in the pipette (extracellular solution or $\left[\mathrm{K}^{+}\right]_{\mathrm{o}}$ ) while the intracellular (bath) $\left[\mathrm{K}^{+}\right]$was maintained at $150 \mathrm{mM}$. Figure 3 shows the single-channel currentvoltage relations at different $\left[\mathrm{K}^{+}\right]_{0}$ concentrations. Figure 4 shows a double-logarithmic plot of the single-channel conductance as a function of $\left[\mathrm{K}^{+}\right]_{\mathrm{o}}$. The data points are fit by a straight line with a slope of $0.42(r=0.99)$. Thus, the relation between singlechannel conductance $(\gamma)$ and $\left[\mathrm{K}^{+}\right]_{0}$ can be expressed as

$$
\gamma(\mathrm{pS})=\mathrm{C} \times\left[\mathrm{K}^{+}\right]_{0}^{0.42}
$$

where $C$ is a constant $=7.24$, and $\left[\mathrm{K}^{+}\right]_{\circ}$ is in $\mathrm{mM}$.

In 10 neonatal membrane patches, the mean $\mathrm{K}_{\mathrm{ATp}}$ channel current per patch was $6.2 \pm 0.61 \mathrm{pA}$ (patch membrane potential $=-60 \mathrm{mV}$ ), which was significantly greater than that of the $I_{K}$ channel $(0.62 \pm 0.05 \mathrm{pA}, n=10, p<0.001)$ measured in another group of neonatal cells. The larger mean $\mathrm{K}_{\mathrm{ATP}}$ current is due to a larger single-channel conductance and higher channel density for the $\mathrm{K}_{\mathrm{ATP}}$ channel as compared with $\mathrm{I}_{\mathrm{K} 1}$ channels in neonatal cells. Figure 5 compares the single-channel conductance of the $\mathrm{K}_{\mathrm{ATP}}$ channel to that of the inwardly rectifying $\mathrm{K}^{+}$channel $\left(\mathrm{I}_{\mathrm{K} I}\right)$ in symmetrical $\left[\mathrm{K}^{+}\right]$. The single-channel conductance of the $\mathrm{K}_{\mathrm{ATP}}$ channel $(56.3 \pm 0.9 \mathrm{pS}, n=14)$ was significantly greater than that of the inwardly rectifying $\mathrm{K}^{+}$channel $(25.0 \pm 0.3 \mathrm{pS}, n=$ $25, p<0.001)$ measured in another group of cells. In physiologic $\left[\mathrm{K}^{+}\right]\left(\left[\mathrm{K}^{+}\right]_{\mathrm{i}}=150 \mathrm{mM},\left[\mathrm{K}^{+}\right]_{\mathrm{o}}=5.4 \mathrm{mM}\right)$, the reversal potential of $K_{\text {ATP }}$ was near $-65 \mathrm{mV}$. Under these conditions, the $K_{\text {ATP }}$ single-channel conductance was also significantly greater than that of the inwardly rectifying $\mathrm{K}^{+}$channel $(14.2 \pm 0.3$ versus 5.1 $\pm 0.2 \mathrm{pS}, p<0.01)$. When the membrane potential was positive

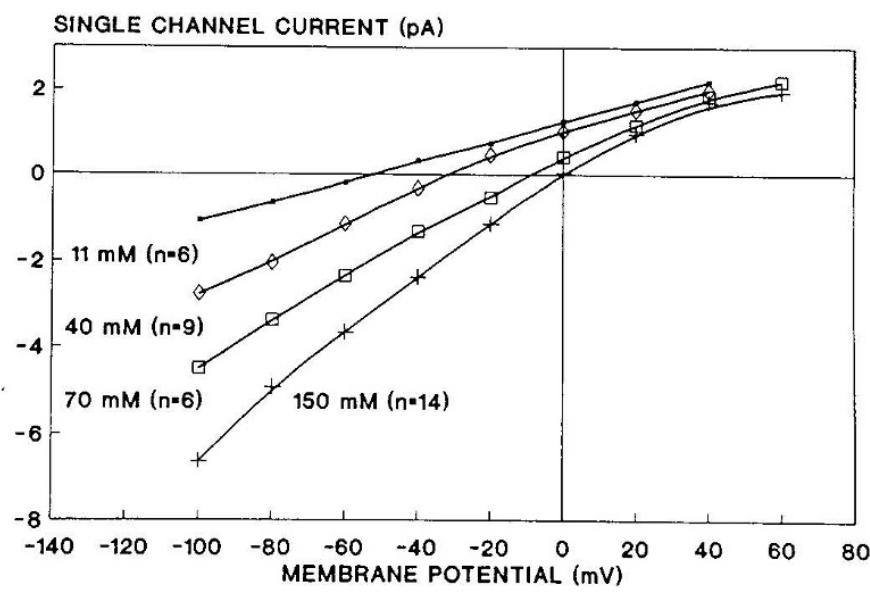

Fig. 3. Dependence of the $\mathrm{K}_{\mathrm{ATP}}$ channel conductance on $\left[\mathrm{K}^{+}\right]_{\mathrm{O}}$. Current-voltage relations of the $\mathrm{K}_{\mathrm{ATP}}$ channel are shown for various external $\mathrm{K}^{+}$concentrations. The single-channel conductance was found to be dependent on $\left[\mathrm{K}^{+}\right]_{0}$. In symmetrical $\mathrm{K}^{+}$concentration $\left(\left[\mathrm{K}^{+}\right]_{\mathrm{o}}=\left[\mathrm{K}^{+}\right]_{\mathrm{i}}=\right.$ $150 \mathrm{mM}$ ), the single-channel conductance of the $\mathrm{K}_{\mathrm{ATP}}$ channel was 56.3 $\pm 0.9 \mathrm{pS}(n=14)$. Decreasing the pipette (extracellular) $\mathrm{KCl}$ concentration shifted the reversal potential of current-voltage relation to the left, consistent with $\mathrm{K}^{+}$as the permeant ion. In lower $\left[\mathrm{K}^{+}\right]_{0}$, the channel conductances were $45.3 \pm 0.8(n=6), 33.7 \pm 0.1(n=9), 20.3 \pm 0.5(n$ $=6$ ), and $14.2 \pm 0.3 \mathrm{pS}$ (not shown, $n=10$ ) at external $\mathrm{K}^{+}$concentrations of $70,40,11$, and $5.4 \mathrm{mM}$, respectively. Little inward rectification of the current-voltage relation is seen, particularly at lower $\left[\mathrm{K}^{+}\right]_{\mathrm{o}}\left(\left[\mathrm{K}^{+}\right]_{\mathrm{i}}=150\right.$ $\mathrm{mM})$.

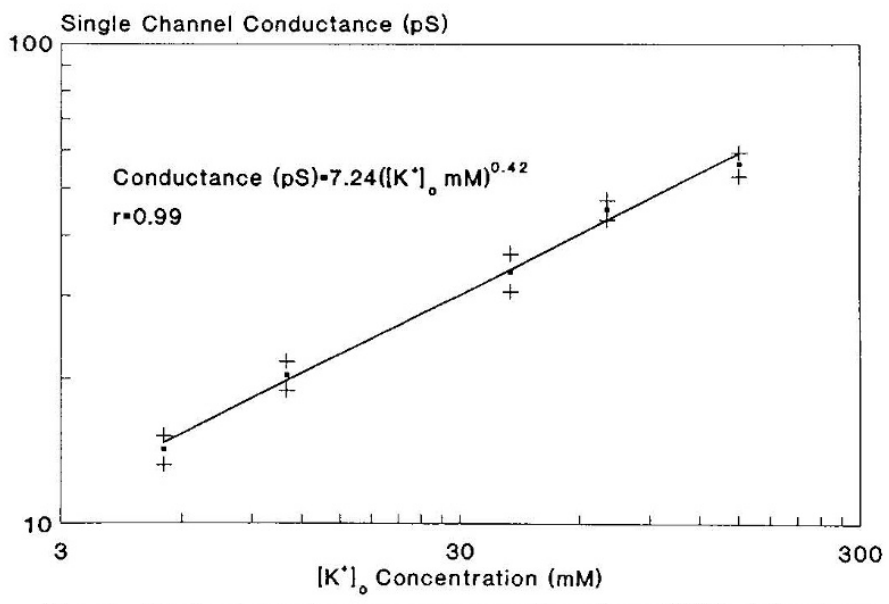

Fig. 4. Single-channel conductance as a function of $\left[\mathrm{K}^{+}\right]_{0}$. The singlechannel conductances calculated from the data of Figure 3 were plotted $v s$ the external $\mathrm{K}^{+}$concentration in a double-logarithmic fashion. The slope of the regression line fitting these points $(0.42)$ yields the exponent of the external $\mathrm{K}^{+}$concentration in the equation relating single-channel conductance to $\left[\mathrm{K}^{+}\right]_{\mathrm{o}}$. For each point, the "+" denotes the SEM.

to the $\mathrm{K}^{+}$equilibrium potential, the $\mathrm{K}_{\mathrm{ATP}}$ channel, in contrast to the $\mathrm{I}_{\mathrm{K} 1}$ channel, carried significant outward current, both in symmetrical and physiologic $\mathrm{K}^{+}$concentrations.

Further, measured $\mathrm{K}_{\mathrm{ATP}}$ channel density in neonatal membrane patches was approximately $3.1 \pm 0.2$ channels/patch $(n=$ 14). This figure is higher than the previously reported channel density for the $I_{\mathrm{K} 1}$ channel in membrane patches from neonatal cardiac cells $(1.84 \pm 0.2$ channels/patch, $n=11, p<0.05)(11)$. Thus, a greater $\mathrm{K}_{\text {ATP }}$ channel density in neonatal ventricular myocytes contributes to the larger mean $\mathrm{K}_{\mathrm{ATP}}$ current with respect to $\mathrm{I}_{\mathrm{K} 1}$

Effects of glibenclamide. In neonatal cell membrane patches, openings of the $\mathrm{K}_{\mathrm{ATP}}$ channel were blocked by $10 \mu \mathrm{M}$ glibenclamide applied to the inside surface of the patch. Glibenclamide appears to affect only $\mathrm{K}_{\mathrm{ATP}}$ channels, inasmuch as it had no 
SINGLE CHANNEL CURRENT (DA)

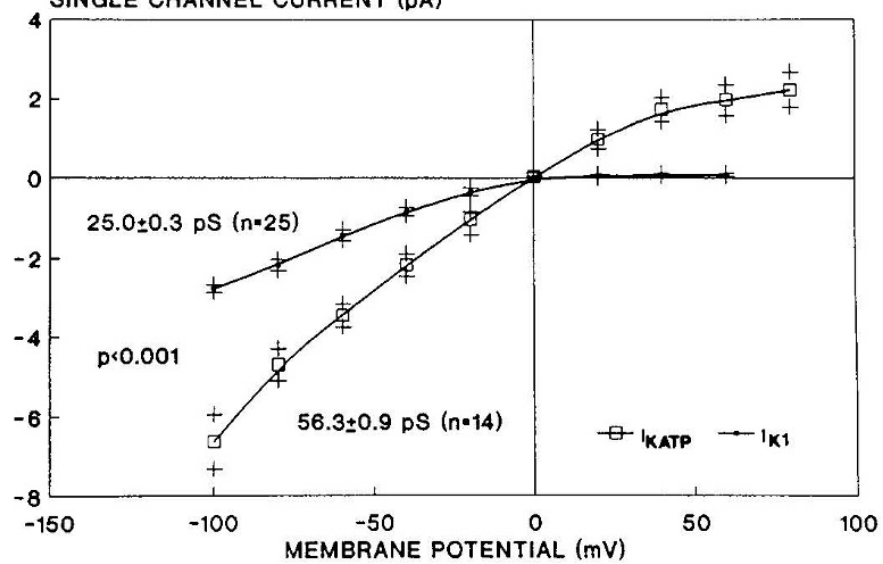

Fig. 5. Comparison of single-channel current-voltage relations for $\mathrm{K}_{\mathrm{ATP}}$ and the inwardly rectifying $\mathrm{K}^{+}$channel $\left(\mathrm{I}_{\mathrm{K} 1}\right)$ in neonatal ventricular myocytes. In symmetrical $\mathrm{K}^{+}$concentration $\left(\left[\mathrm{K}^{+}\right]_{\mathrm{o}}=\left[\mathrm{K}^{+}\right]_{\mathrm{i}}=150 \mathrm{mM}\right)$, the single-channel conductance for $\mathrm{K}_{\mathrm{ATP}}$ is significantly larger than that for $\mathrm{I}_{\mathrm{K}_{1}}(p<0.001)$. Also note that the inward rectification seen in the $\mathrm{I}_{\mathrm{K} 1}$ current-voltage relation is much less pronounced for $\mathrm{K}_{\mathrm{ATP}}$ channels.
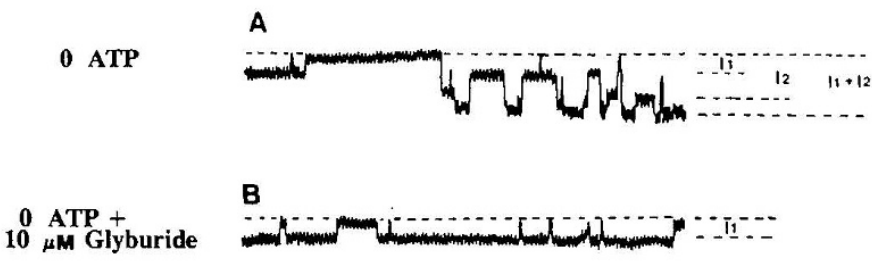

0 ATP

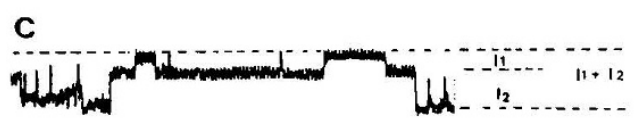

$$
4 \mathrm{pA} \bigsqcup_{200 \mathrm{~ms}}
$$

Fig. 6. The effect of glibenclamide on the $\mathrm{I}_{\mathrm{K} 1}$ channel. $A$, Removing ATP from the bath solution resulted in opening of $\mathrm{K}_{\mathrm{ATP}}$ channels. This record shows two distinct classes of channels with different single-channel conductances. With the membrane patch held at $-60 \mathrm{mV}$, the smaller unitary current channel $\left(I_{l}\right)$ is consistent with $\mathrm{I}_{\mathrm{K} 1}$ and the larger unitary current channel displayed properties consistent with current through the $\mathrm{K}_{\mathrm{ATP}}$ channel $\left(I_{2}\right) . B$, Ten $\mu \mathrm{M}$ glibenclamide (glyburide) blocked the $\mathrm{K}_{\mathrm{ATP}}$ channel $\left(I_{2}\right)$ but had no effect on current through the $I_{K 1}$ channel $\left(I_{1}\right)$, indicating that glibenclamide appears to be a specific $\mathrm{K}_{\mathrm{ATP}}$ channel blocker at this concentration. $C$, After washing out glibenclamide, openings of both channels are again observed.

significant effect on $\mathrm{I}_{\mathrm{K} 1}$ currents (Fig. 6). It was found that both the estimated number of functional channels and the duration of channel openings were decreased by $10 \mu \mathrm{M}$ glibenclamide in neonatal membrane patches, whereas the unitary current amplitude determined at either negative or positive membrane potentials remained unchanged. At a membrane potential of $-60 \mathrm{mV}$, addition of glibenclamide significantly reduced $\mathrm{P}_{\text {open }}$ from 0.49 \pm 0.02 to $0.04 \pm 0.02(n=10, p<0.001)$. Glibenclamide also decreased the estimated number of functioning $K_{\text {ATP }}$ channels from $2.61 \pm 0.18$ to $1.23 \pm 0.11$ per patch $(n=10, p<0.05)$. Consequently, glibenclamide decreased the $\mathrm{I}_{\text {mean }}$ from $6.2 \pm 0.61$ to $0.69 \pm 0.11 \mathrm{pA}(n=10, p<0.01)$.

Effect of removing intracellular ATP on whole cell $K^{+}$currents and action potential. Figure 7 demonstrates changes in whole cell $\mathrm{K}^{+}$current $(A)$ and action potential duration $(B)$ upon puncture of the cell membrane (left traces) and after dialysis of the cell with ATP-free internal solution for $20 \mathrm{~min}$ (right traces). After 20 min of dialysis, the outward current at the end of an
A
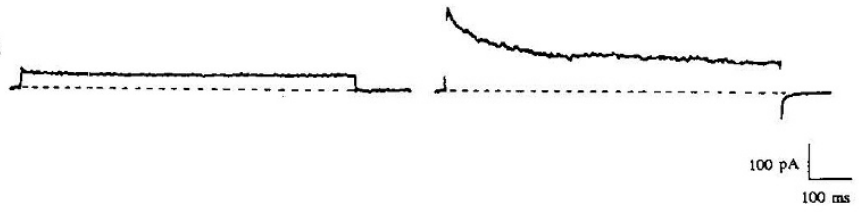

B
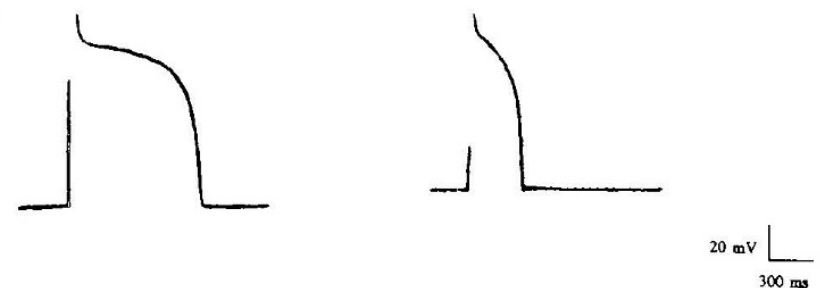

Fig. 7. Effects of removing ATP on the whole cell outward $\mathrm{K}^{+}$current $(A)$ and action potential duration $(B)$. A, Current recorded immediately upon puncture of the cell membrane (intracellular ATP concentration nearly normal) was $41.5 \mathrm{pA}$ (cell membrane clamped to $+40 \mathrm{mV}$ for $800 \mathrm{~ms}$ from a holding potential of $-80 \mathrm{mV}$, left trace). After $20 \mathrm{~min}$ of dialysis with ATP-free internal solution, the current for an identical clamp step increased to $112.2 \mathrm{pA}$ (right trace). $B$, Under the same conditions, the action potential duration shortened from $910 \mathrm{~ms}(l e f t)$ to $380 \mathrm{~ms}$ (right).

800 -ms clamp step to $+40 \mathrm{mV}$ increased from $37.6 \pm 7.4$ to 91.4 $\pm 6.7 \mathrm{pA}(n=7, p<0.01$, holding membrane potential $=-80$ $\mathrm{mV})$. Under similar conditions, the action potential duration shortened by $43.7 \pm 12 \%$ over the 20 -min period. Lowering ATP in the internal solution appeared to have no significant effect on resting membrane potential (data summarized in Fig. 8).

Comparison of $K_{\mathrm{ATP}}$ channel properties between neonatal and adult cells. The single-channel conductance, channel density, and open-state probability were compared between neonatal and adult rabbit ventricular myocytes (Fig. 9). Open-state probability was $0.42 \pm 0.06$ in neonates $(n=14)$, which was not statistically different from that measured in the adult $(0.38 \pm 0.08, n=13)$. However, in symmetrical $\mathrm{K}^{+}$concentration $\left(\left[\mathrm{K}^{+}\right]_{\mathrm{o}}=\left[\mathrm{K}^{+}\right] ;=150\right.$ $\mathrm{mM}$ ), the single-channel conductance of the $\mathrm{K}_{\mathrm{ATP}}$ channel in neonatal cells was $56.3 \pm 0.9 \mathrm{pS}(n=14)$, which was significantly smaller than that in adult ventricular myocytes $(65.6 \pm 0.7 \mathrm{pS}$, $n=11, p<0.01$ ). In addition, it was found that the estimated $\mathrm{K}_{\mathrm{ATP}}$ channel density in neonatal rabbit ventricular myocytes $(3.1 \pm 0.3$ per patch, $n=14)$ was significantly lower than that in adult cells $(5.1 \pm 0.7$ per patch, $n=8, p<0.05)$.

\section{DISCUSSION}

We have identified an ATP-sensitive $\mathrm{K}^{+}$channel in excised membrane patches from freshly isolated neonatal rabbit ventricular myocytes. Our results suggest that the $\mathrm{K}_{\mathrm{ATP}}$ channel in neonatal ventricular myocytes shares many of the properties of the $\mathrm{K}_{\mathrm{ATP}}$ channel reported in other preparations. The conductance of the $\mathrm{K}_{\mathrm{ATP}}$ channel in neonatal rabbit cardiac cells is more than twice that of the inwardly rectifying $\mathrm{K}^{+}$channel, and the current-voltage relation shows little inward rectification when measured in physiologic concentrations of $\mathrm{K}^{+}$. Moreover, we have shown that removal of ATP from the cytoplasmic side of neonatal ventricular myocytes increased $\mathrm{K}^{+}$outward current and shortened the action potential duration, indicating that $\mathrm{K}_{\mathrm{ArP}}$ channels in immature heart function in a manner similar to that reported for adult cardiac tissue. In addition, developmental differences in the properties of the $K_{A T P}$ channel were demonstrated in the present study. In adult ventricular myocytes, the single-channel conductance of the $K_{A T P}$ channel was significantly larger and the channel density higher than in neonatal cells.

The effects of glibenclamide on $\mathrm{K}_{\mathrm{ATP}}$ channels in immature cardiac tissue have not been reported previously. In the present study, we have shown that $10 \mu \mathrm{M}$ glibenclamide almost com- 
A

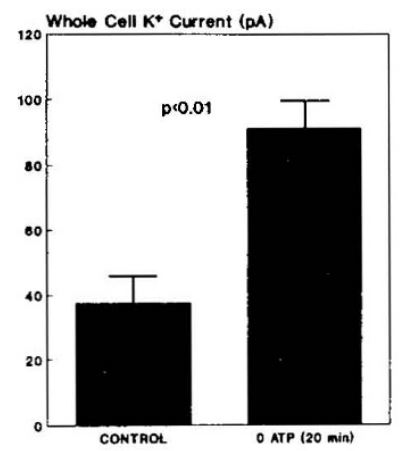

B

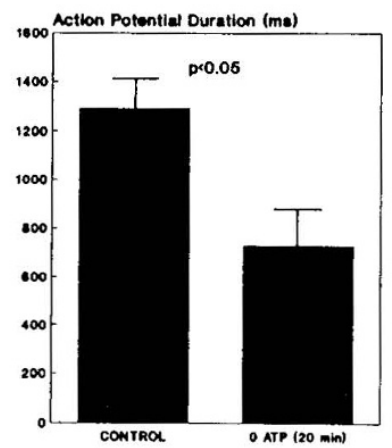

C

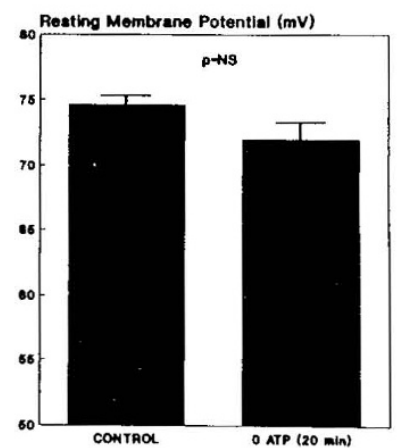

Fig. 8. Effects of eliminating intracellular ATP on whole cell current, action potential duration, and resting membrane potential. $A$, In a group of neonatal cells, removing ATP from the internal solution caused a significant increase in the outward $\mathrm{K}^{+}$current from $37.6 \pm 7.4$ to $91.4 \pm 6.7$ $\mathrm{pA}$ upon clamping from $-80 \mathrm{mV}$ to $+40 \mathrm{mV}$ for $800 \mathrm{~ms}(n=7, p<0.01)$. B, Deleting ATP from intracellular solution caused a decrease in the action potential duration from $1290 \pm 140$ to $726 \pm 181 \mathrm{~ms}$ in another group of neonatal cells $(n=8, p<0.05)$. $C$, Eliminating ATP from the internal solution caused no significant change in the resting membrane potential $(-74.6 \pm 0.5$ compared to $-72.0 \pm 1.1 \mathrm{mV}, p>0.05)$.

A

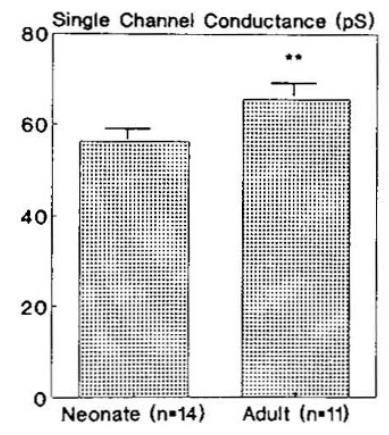

B

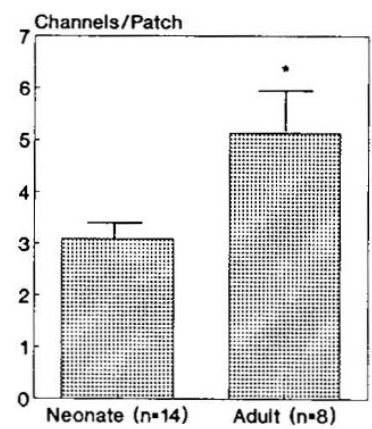

C

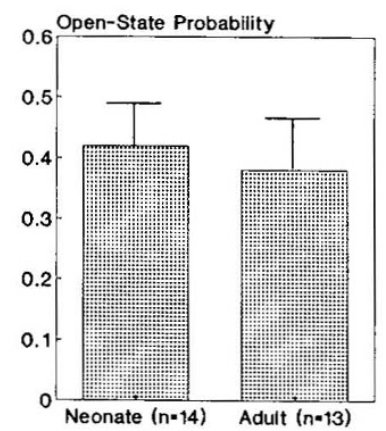

Fig. 9. Comparison of $\mathrm{K}_{\mathrm{ATP}}$ channel properties between neonatal and adult cells. $A$, Comparison of the single-channel conductance of $\mathrm{K}_{\mathrm{ATP}}$ channel in neonatal cells and adult cells. $B$, The estimated $\mathrm{K}_{\mathrm{ATP}}$ channel density in neonatal rabbit ventricular myocytes was significantly lower than that in adult cells. $C$, The open-state probability of the $\mathrm{K}_{\mathrm{ATP}}$ channel was not significantly different between the two age groups $(n=13 ; p=\mathrm{NS})$. $\left(\left[\mathrm{K}^{+}\right]_{\mathrm{o}}=\left[\mathrm{K}^{+}\right]=150 \mathrm{mM}\right.$, holding membrane potential $=-60 \mathrm{mV} ;{ }^{* *}, p<0.01 ; *, p<0.05$. $)$

pletely blocked the $\mathrm{K}_{\mathrm{ATP}}$ channels in neonatal ventricular myocytes. Glibenclamide reduced channel open-state probability and channel number, consequently decreasing outward $\mathrm{K}^{+}$current. These findings are consistent with the effects of glibenclamide in other preparations (8). It is possible that glibenclamide may have clinical benefit in preventing action potential shortening, $\mathrm{K}^{+}$ efflux, and subsequent arrhythmias in neonatal myocardium under conditions of relative hypoxia and ischemia, as has been suggested for adult myocardium $(17,18)$.

In comparing the properties of the $\mathrm{K}_{\mathrm{ATP}}$ channel between neonatal and adult myocytes, we found a significantly greater single-channel conductance in the adult, suggesting developmental changes in the ability of individual channels to pass $\mathrm{K}^{+}$ ions. This finding is in concert with results from our laboratory and others showing that the single-channel conductance of the $I_{K 1}$ channel increases significantly with age $(11,19)$ and that whole cell $\mathrm{K}^{+}$currents undergo age-related increases (20). However, it must be remembered that the contribution of $\mathrm{K}_{\mathrm{ATP}}$ channels to whole cell conductance is dependent not only on single $\mathrm{K}_{\mathrm{ATP}}$ channel conductance but also on $\mathrm{K}_{\mathrm{ATP}}$ channel density. In earlier studies in mature myocytes, Noma and Shibasaki (4) reported that $K_{A T P}$ channel density was almost equal to $I_{K 1}$ channel density. In contrast, recent studies suggest that the $\mathrm{K}_{\mathrm{ATP}}$ channel density may be quite high, particularly with respect to the density of $I_{K 1}$ channels $(17,21)$. Our results indicated that the channel density ratio $\mathrm{K}_{\mathrm{ATP}} / \mathrm{I}_{\mathrm{K} 1}$ increased from $1.68(3.1 / 1.84)$ in neonatal cells to $2.34(5.1 / 2.18)$ in adult myocytes. These data must be interpreted with some caution because if $\mathrm{P}_{\text {open }}$ is relatively low, the calculation of channel number from maximum channel superposition may underestimate the real channel density. Nonetheless, the comparison of $\mathrm{K}_{\mathrm{ATP}}$ to $\mathrm{I}_{\mathrm{K} 1}$ channel density in the two age groups suggests that the functional significance of the $\mathrm{K}_{\mathrm{ATP}}$ channel may be somewhat blunted in the metabolically disadvantaged immature myocardium as compared with ischemic adult myocardium.

In summary, the $\mathrm{K}_{\mathrm{ATP}}$ channel has been characterized in neonatal rabbit ventricular myocytes. $K_{A T P}$ channels in neonatal cells are activated when ATP is excluded from the intracellular milieu. Opening of these channels results in increased outward $\mathrm{K}^{+}$current and action potential shortening. Consequently, electrical conduction and mechanical function may be altered. The density and single-channel conductance of these channels increases in an age-dependent manner without significant alteration in the open-state probability. These findings may have important implications for the relative ability of neonatal and adult myocardium to respond to hypoxia and ischemia.

Acknowledgments. The authors thank Dr. J. N. Weiss for his encouragement, technical assistance, and valuable advice and $\mathrm{S}$. Warren for her help in the preparation of this manuscript.

\section{REFERENCES}

1. Katz AM 1977 Physiology of the Heart. Raven Press, New York, pp 229-256 2. Josephson IR, Brown AM 1986 Inwardly rectifying single-channel and whole cell $\mathrm{K}^{+}$currents in rat ventricular myocytes. J Membrane Biol 94:19-35

3. Isenberg $\mathrm{G}$, Vereecke J, Van der Heyden G, Carmeliet E 1983 The shortening of the action potential by DNP in guinea-pig ventricular myocytes is mediated by an increase of a time-independent $\mathrm{K}$ conductance. Pflugers Arch 397:251-259 
4. Noma A, Shibasaki $\mathrm{T} 1985$ Membrane current through adenosine-triphosphate-regulated potassium channels in guinea-pig ventricular cells. J Physiol (Lond) 363:463-480

5. Weiss J, Shine KI 1982 Extracellular $\mathrm{K}^{+}$accumulation during myocardial ischemia in isolated rabbit. Am J Physiol 242:H619-H628

6. Noma A 1983 ATP-regulated $\mathrm{K}^{+}$channels in cardiac muscle. Nature 305:147148

7. Kakei M, Noma A, Shibasaki T 1985 Properties of adenosine-triphosphateregulated potassium channels in guinea-pig ventricular cells. J Physiol (Lond) 363:441-462

8. Ashcroft FM 1988 Adenosine 5'-triphosphate-sensitive potassium channels. Annu Rev Neurosci 11:97-118

9. Kirsch GE, Codina J, Birnbaumer L, Brown AM 1990 Coupling of ATP sensitive $\mathrm{K}^{+}$channels to $A_{1}$ receptors by $G$ proteins in rat ventricular myocytes. Am J Physiol 259:H820-H826

10. Chin TK, Friedman WF, Klitzner TS 1990 Developmental changes in cardiac myocyte calcium regulation. Circ Res 67:574-579

11. Chen F, Wetzel GT, Friedman WF, Klitzner TS 1991 Single-channel recording of inwardly rectifying potassium currents in developing myocardium. J Mol Cell Cardiol 23:259-267

12. Wetzel GT, Chen F, Friedman WF, Klitzner TS 1991 Calcium current measurements in acutely isolated neonatal cardiac myocytes. Pediatr Res 30:8389

13. Hamill OP, Marty A, Neher E, Sakmann B, Sigworth FJ 1981 Improved patch- clamp techniques for high-resolution current recording from cells and cellfree membrane patches. Pflugers Arch 391:85-100

14. Weiss JN, Lamp ST 1987 Glycolysis preferentially inhibits ATP-sensitive $\mathrm{K}^{+}$ channels in isolated guinea-pig cardiac myocytes. Science 238:67-69

15. Weille J, Schmid-Antomarchi H, Fosset M, Lazdunski M 1988 ATP-sensitive $\mathrm{K}^{+}$channels that are blocked by hypoglycemia-inducing sulfonylureas in insulin-secreting cells are activated by galanin, a hyperglycemia-inducing hormone. Proc Natl Acad Sci USA 85:1312-1316

16. Marty A, Neher E 1983 Tight-seal whole-cell recording. In: Sakmann B, Neher E (eds) Single-Channel Recording. Plenum Press, New York, pp 107-122

17. Carmeliet E, Storms L, Vereecke J 1990 The ATP-dependent K-channel and metabolic inhibition. In: Zipes DP, Jalife J (eds) Cardiac Electrophysiology From Cell to Bedside. Saunders, Philadelphia, pp 103-108

18. Kantor PF, Coetzee WA, Carmeliet EE, Dennis SC, Opie LH 1990 Reduction of ischemic $\mathrm{K}^{+}$loss and arrhythmias in rat hearts: effect of glibenclamide, a sulfonylurea. Circ Res 66:478-485

19. Josephson IR, Sperelakis N 1989 Developmental changes in the inwardlyrectifying $\mathrm{K}^{+}$current. Circulation 80 :II-144

20. Huynh TV, Chen F, Wetzel GT, Friedman WF, Klitzner TS 1991 Developmental changes in membrane $\mathrm{Ca}^{2+}$ and $\mathrm{K}^{+}$currents in fetal, neonatal, and adult heart cells. Circ Res 70:508-515

21. Nichols CG, Lederer WJ 1990 The regulation of ATP-sensitive $\mathrm{K}^{+}$channel activity in intact and permeabilized rat ventricular myocytes. $\mathbf{J}$ Physiol (Lond) 423:91-110 